\title{
The Urgency of Entrepreneurial Learning Model to Instill the Independence of Santri at Ibnu Fatah Orphanage, Pengasih, Kulon Progo
}

\author{
Lue Sudiyono \\ A Dean of Guidance and Counseling Program, Faculty of Education, \\ Institute of Teacher Training and Education of the Indonesian Teachers Association \\ (IKIP PGRI),Wates, Yogyakarta \\ Corresponding Author
}

Doi:10.5901/mjss.2017.v8n3p197

\begin{abstract}
The present study aims to determine the pattern of education which is usually applied in orphanages, especially Ibnu Fatah Orphanage, Pengasih, Kulon Progo and to provide a model of entrepreneurial learning which becomes the basis of instilling the attitude of independence among santri at Ibnu Fatah to be developed as the curriculum in accordance with the rules of education in the orphanage. After designing the suitable curriculum, the implementation of skill and entrepreneur guidebook such as sewing clothes, digital printing and other skills is arranged as future provisions of Santri (students at Islamic boarding school or Islamic orphanages). The study implemented qualitative approach. Primary data were obtained from the questionnaires given to Santri who became the informant and were analyzed in descriptive statistics model. On the other hand, secondary data from the caregivers and the management of the orphanage were conducted with interviews, experimental and triangulation. There are four stages in conducting interactive descriptive analysis: 1) Data Collection; 2) Data Reduction; 3) Data Display; 4) Conclusions: Drawing/verifying. The results showed the caregivers, management, and Santri highly expect the skill and entrepreneurial education which can be directly applied to be the additional income in the orphanage with a request for help and the participation of several parties since the orphanage have limited infrastructure and human resources.
\end{abstract}

Keywords: Entrepreneurial Learning, Independence, Orphanage

\section{Introduction}

In response to the future challenges, a good education system needs to be designed as early as possible, since it demands all parties to strengthen their identity by creating their image as an independent and skillful person. Therefore, what seems as an effective strategy to face this advancement is by improving the system at formal, non-formal and informal education. It is supported by Maliki (2010: 5) who stated that education can contribute to the enlightenment, offer each person or group to make changes to address the gaps, achieve prosperity, and help to improve the ability to anticipate and filter the information.

Furthermore, according to Law No.20 of 2003 article 3 on national education system stating that national education is aimed at developing students' potentials to be individuals who are faithful, pious, healthy, knowledgeable, skilled, creative, independent, have noble character, and become democratic and responsible citizen, so that they do not depend on other people economically in achieving physical and emotional wellbeing. Therefore, independence and entrepreneurship education need to be given as early as possible to be the provision of living for children and society. Soemanto (1984) strengthened that entrepreneurship education is a process to instill courage, virtue, and strength to fulfill the needs and to solve the problems of life.

Hasan (2013) stated that education given at boarding schools and orphanages is often oriented to teach and discuss about heaven and hell neglecting materials preparing the students to be independent to face real life challenges, given the fact that independence is not formed by nature, yet through an education process, for instance, habituation, providing insight, and training. Independence of someone is at least influenced by two factors, parenting by family and education at schools.

What becomes the problem is what about children who do not have or, for some reasons, do not live with family? In this case, orphanage becomes an institution that accommodates children who do not have families or do not live with the family. Orphanage is institutionally included into non-formal education.

As explained by Sudjana (2004: 146), units of non-formal education consist of courses, training, study groups, learning centers, religious teaching group, and similar educational units. Similar educational units refer to agencies, 
apprenticeship institutions or centers, counseling, tutoring, boarding schools, hermitage, studio, crèche, elderly activities, and communication education at mass media.

In Kulon Progo, there are 17 orphanages facing the same problems, such as limited caregivers who meet the educational qualifications, so that orphanage merely provides access to education or becomes the place to stay. Of the various problems faced by the orphanages, it can be identified as follows:

1) more complex future challenges as the impact of globalization,

2) minimum care given by the orphanages due to the lack of caregivers that meets the educational qualifications, and

3) Insufficient life skill of the students when graduate, for the orphanages do not maximally facilitate and foster them to develop their skill.

From the problem stated above, it can be concluded that education system and curriculum development in orphanages tend be not well-arranged to instill the attitude of independence among santri to face future challenges.

\section{Research Method}

The study implemented quantitative approach to obtain primary data and qualitative approach to collect secondary data. The main instrument was the researcher. Observation and experimentation of 20 santri through questionnaires were conducted. In-depth interview with one caregiver and one personnel of the management was carried out. Other instruments, such as notebook, camera, and tape recorder, were used as means of obtaining the data when doing the triangulation.

\subsection{Data Collection}

To get the data related to the variables examined, the data were obtained from questionnaires in which there were several questions given to santri. Besides, the data were also collected from interview with the caregivers and the management of the orphanage. The data from interview were then analyzed qualitatively in a natural setting to provide an understanding and a broader picture that give interpretation to the phenomenon as seen from the meaning and strengthen the results of a study of the problems that arise (Creswell, 2009). This study is categorized as phenomenological research. Denzin and Lincoln (2009 cited in Lue.S. 2012: 30) stated that qualitative research tends to be phenomenological, however most of them are not radical but idealistic views to provide an understanding of the interpretation of the results.

\subsection{Research Design and Scope}

In this study, there are several activities, such as:

a. observation when guiding students who do internship in some orphanages to see some problems in the orphanage,

b. conducting experiments and pretest to determine a cursory understanding of students about entrepreneurship education and counseling about the benefits of having life-skills, independence and entrepreneurship, and motivation,

c. conducting posttest by randomly giving questionnaire about independence and motivation to 20 santri who have graduated from SLP/SLA,

d. carrying out Interview with one caregiver and one personnel of the management focusing on the conditions of the orphanage in general, santri, infrastructure, and the implementation of activities in the orphanage, and

e. Analyzing the data with interactive analysis technique.

\subsection{Data analysis}

The methods used in the analysis are:

1) descriptive statistics analysis used to analyze the questionnaire by describing the data and calculating the percentage (\%), and

2) Interactive analysis model by Miles and Huberman (1992 cited in Denzin \& Lincoln, 2009: 592) consisting of four stages: a) data collection; b) data reduction; c) data display; and d) conclusions: drawing/ verifying which is illustrated in the diagram below 


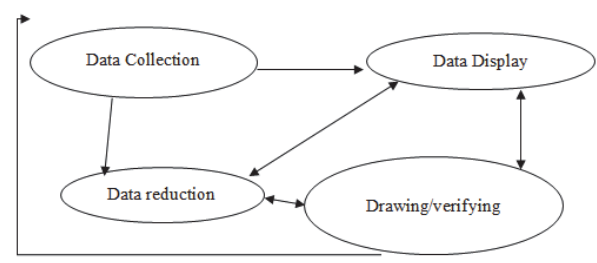

Figure 1. Component of Interactive Model Data Analysis

Source: Miles \& Huberman (1994 cited in Denzin \& Lincoln, 2009: 592)

\section{Results and Discussion}

\subsection{Profile of Ibnu Fatah Orphanage}

Ibnu Fattah Orphanage is a social institution focusing on tackling social problems especially the orphans and the poor. This social institution was established based on the Notarial Deed dated March 24, 2008 issued by Ahmad Dien Prawirakarsa, S.H and obtained operating permits from the Department of Social Welfare of DIY by numbers: 222/50/GR.I/2012 which has been extended and updated once.

Ibn Fattah Orphanage was founded by Arwan Zuwardi located in Karangtengah Kidul Margosari, Pengasih, Kulon Progo. In 2008 -2010, the orphanage rented two houses in RT 09. In 2009 the orphanage bought $6000 \mathrm{~m}^{2}$ land area and the construction of the building was started. In February, 2010, Ibn Fattah moved to the present building, which is located at RT 08, even though some buildings were still under construction. Up to 2013, there are 80 santri at the orphanage coming from Kulon Progo, Wonosobo, Purbalingga, Brebes, Bogor, and Flores.

\subsection{Patterns of Education}

The schedule of daily and weekly activities has been arranged. Skills activities started at 15:30 to 17:00 every Thursday which means its portion is merely 90 minutes (11.2\%) within 7 days. It can be seen in the following table:

Table 1. Schedule of Daily Activities

\begin{tabular}{|c|c|l|}
\hline No & Time & Activity \\
\hline 1 & $04.00-05.15$ & Quran recitation, Fajr prayer \& study \\
\hline 2 & $05.15-06.30$ & Cleaning up environment \\
\hline 3 & $06.30-13.30$ & Studying at school \\
\hline 4 & $13.30-15.00$ & Lunch break \\
\hline 5 & $15.00-17.00$ & Asr prayer, skills, sports, computers, etc. \\
\hline 6 & $17.00-18.00$ & Cleaning up the Environment and Quran recitation \\
\hline 7 & $18.00-19.00$ & Maghrib prayer, religious teaching group, Islamic studies \& Isha prayers \\
\hline 8 & $19.00-21.00$ & Study \\
\hline 9 & $21.00-04.00$ & Sleep \\
\hline
\end{tabular}

Source: Caregivers of the Orphanage, 2014

Table 2. Schedule of Weekly Activities

\begin{tabular}{|c|c|c|l|}
\hline No & Day & Time & Activity \\
\hline 1 & Monday & $15.30-17.00$ & English \\
\hline 2 & & $18.00-19.00$ & Aqidah and Akhlak \\
\hline 3 & Tuesday & $15.30-17.00$ & Self-defense \\
\hline 4 & & $18.00-19.00$ & History and Hadiths \\
\hline 5 & Wednesday & $15.30-17.00$ & Sports \\
\hline 6 & & $18.00-19.00$ & Qiro'ati \\
\hline 7 & Thursday & $15.30-17.00$ & Skills/automotive/agriculture \\
\hline
\end{tabular}




\begin{tabular}{|c|l|c|l|}
\hline No & Day & Time & Activity \\
\hline 8 & & $18.00-19.00$ & Rhetoric of propagation \\
\hline 9 & Friday & $15.30-17.00$ & Computer \\
\hline 10 & & $18.00-19.00$ & Arabic \\
\hline 11 & Saturday & $15.30-17.00$ & Digital printing \\
\hline 12 & & $18.00-19.00$ & Fiqh \\
\hline 13 & Sunday & $04.00-05.15$ & Organisation \\
\hline 14 & & $08.00-12.00$ & Sports, cleaning up the environment \\
\hline 15 & & $18.00-19.00$ & Practical worship \\
\hline
\end{tabular}

Source: Caregivers of the Orphanage, 2014

\subsection{Education Model}

Result obtained from questionnaire on entrepreneurship education showed that $95 \%$ respondents do not know the presence of skill or vocational education at the orphanage. $97 \%$ of female respondents also have the same answer. However, $24 \%$ of them were given computer skill material at school. If training on sewing or digital printing is given to them, $98 \%$ santri stated they are willing to follow. Thus, if santri is given vocational education for future preparation, they are willing to participate.

From the interviews with caregivers and management of the orphanage, two years ago (2012) the orphanage was given 1 sewing machines and there was also a teacher from vocational high school who coached six santri approximately 4-5 times. However the activity did not last longer since the teacher was busy preparing teacher certification.

\subsection{Developing the Curriculum}

Based on the result of interview with caregivers and management of the orphanage, they argued that in fact the manager highly needs entrepreneur education/training at the orphanage. However, due to limited funds and human resources, it has not been realized yet. Caregivers and management stated that the orphanage needs help and participation from several stakeholders, especially society and the government, to significantly contribute to the development of the orphanage.

\section{Conclusion}

\subsection{Conclusion}

Based on the results, it can be concluded that:

a. The pattern of education in the orphanages at Kulon Progo, Yogyakarta, based on the daily and weekly schedule of activities, $72 \%$ activities is allocated for religious activities, $11.2 \%$ for skills activities, and $16.8 \%$ for sports activities, cleaning up the environment, and other activities.

b. Entrepreneurial learning to instill the attitude of independence is highly possible to be applied at the orphanage, particularly Ibnu Fatah Orphanage since 98\% respondents agree to join training of entrepreneurship, like sewing or digital printing, if it is conducted.

c. The development of appropriate curriculum at the orphanage highly depends on the presence of infrastructure and human resources to implement.

\subsection{Suggestions}

a. For the sake of progress and life provision of santri in the future, it is necessary to instill the attitude of independence among santri by providing them skill or vocational education and training based on religious least $60 \%$ and other activities $40 \%$ implemented in the daily schedule.

b. Society and governments should participate in the development of education in Indonesia, for instance, by providing infrastructure and human resources needed by the orphanage. 


\section{References}

Creswell, J.W. (2009). Research Design, Qualitative, Quantitative, and Mixed Methods Approaches. Los Angeles: Sage Publications. Denzin, N. K., \& Lincoln, Y. S. (2009). Qualitative Research. Yogyakarta. Pustaka Pelajar.

Sudiyono, L. (2012). Partisipasi Masyarakat Dalam Pembangunan Pendidikan. Dissertation. Malang. UNMER Malang. Maliki, Z. (2010). Sosiologi Pendidikan. Yogyakarta. Gadjah Mada University Press.

Miles, MB. \& Huberman, AM. (1994). Qualitative Data Analysis (2nd edition). Thousand Oaks, CA: Sage Publications. Mujiman, H. (2009). Manajemen Pelatihan Berbasis Belajar Mandiri. Yogyakarta. Pustaka Pelajar.

Sudjana, N. (2004). Dasar-dasar Proses Belajar Mengajar. Sinar Baru Algensindo. Bandung.

Sugiyono. (2010). Metode Penelitian Pendidikan Pendekatan Kuantitatif dan Kualitatis dan R \& D. Alfabeta. Bandung. Soemanto, W. (2002). Pendidikan Kewiraswastaan. Bumi Aksara. Jakarta.

Wickham, P.A. (2006). Strategic Entrepreneurship, 4th Edition. USA. Pearson. 
ISSN 2039-2117 (online)

ISSN 2039-9340 (print)
Mediterranean Journal of Social Sciences MCSER Publishing, Rome-Italy
Vol 8 No 3

May 2017 